2. Kahlson, G., Rosengren, E., and Westling, H.: Increased formation of histamine in the pregnant rat. J. Physiol., 143: 91 (1958).

3. Kahlson, G., Rosengren, E., Westling, H., and White, T.: The site of increased formation of histamine in the pregnant rat. J. Physiol., 144: 337 (1958).

4. Kahlson, G., Rosengren, E., and White, T.: Formation of histamine by the foetus in the rat and man. J. Physiol., 145: 30 (1960).

5. Kahlson, G., Rosengren, E., and White, T.: The formation of histamine in the rat foetus. J. Physiol., 151: 131 (1960).

6. Nitzan, M., and Groffman, H.: Glucose metabolism in experimental intrauterine growth retardation. Biol. Neonate, 17: 420 (1971).

7. Oh, W., D'Amodio, M. D., Yap, L. L., and Hohenauer, L.: Carbohydrate metabolism in experimental intrauterine growth retardation in rats. Amer. J. Obstet. Gyneco., 108: 415 (1970).

8. Reilly, M. A., and Schayer, R. W.: Further studies on the histidine-histamine relationship in vivo: Effects of endotoxin and of histidine decarboxylase inhibitors. J. Pharmacol., 34: 551 (1968).

9. Schayer, R. W.: Relationship of stress-induced histidine decarboxylase to circulatory homeostoses and shock. Science, 131: 226 (1960).

10. Schayer, R. W.: Relationship of induced histidine decarboxylase activity and histamine synthesis to shock from stress and from endotoxin. Amer. J. Physiol., 198: 1187 (1960).

11. Schayer, R. W.: Significance of induced synthesis of histamine in physiology and

Copyright (c) 1976 International Pediatric Research Foundation, Inc. pathology. Chemotherapia, 3: 128 (1961).

12. Schayer, R. W.: Evidence that induced histamine is an intrinsic regulator of the microcirculatory system. Amer. J. Physiol., 202: 66 (1962).

13. Schayer, R. W.: Induced synthesis of histamine, microcirculatory regulation and the mechanism of action of the adrenal glucocorticoid hormones. Progr. Allergy, 7: 187 (1963).

14. Schayer, R. W.: Histamine and autonomous responses of the microcirculation; relationship to glucocorticoid action. Ann. N. Y. Acad. Sci., 116:891 (1964).

15. Schayer, R. W : Enzymatic formation of histamine from histadine. In: M. Rocha e Silva: Handbook of Experimental Pharmacology. Part I. Histamine: Its Chemistry, Metabolism and Physiological and Pharmacological Actions, pp. 688-725 (Springer-Verlag, New York, 1966).

16. Wigglesworth, J. C.: Experimental growth retardation in the foetal rat. J. Pathol. Bacteriol., 88: 1 (1964).

17. Winick, M.: Cellular growth in intrauterine malnutrition. Pediat. Clin. N. Amer., 17: 69 (1970).

18. Dr. M. S. Kwong is a Fellow supported by the National Institutes of Health, Grant IF02 HD-53520-01

19. Requests for reprints should be addressed to: D. W. Thibeault, M.D., Department of Pediatrics, Harbor General Hospital, 1000 W. Carson St., Torrance, Calif. 90509 (USA).

20. Accepted for publication February 25, 1976.
Bacterial activity chronic granulomatous disease glucose-6-P dehydrogenase lability
glucose-6-P dehydrogenase Mediterranean variant

leukocytes

nitroblue tetrazolium

Printed in U.S.A.

\title{
Leukocyte Function and Characterization of Leukocyte Glucose-6-phosphate Dehydrogenase in Sicilian Mutants
}

\author{
GINO SCHILIRÒ, ${ }^{(25)}$ ANTONIO RUSSO, LUISA MAURO, GIUSEPPE PIZZARELLI, \\ AND SANTO MARINO \\ Departments of Paediatrics and Hygiene, University of Catania, Catania, Italy
}

\section{Extract}

Nine Sicilian children known to be deficient in glucose-6-phosphate dehydrogenase (G6PD) were studied to see if there were anomalies of bactericidal activity in peripheral blood phagocytes. The type of deficiency was established. The G6PD levels in the leukocyte were found to be $26 \%$ of the controls $(0.094 \pm 0.03$, normal controls $0.360 \pm 0.12$ ). The Michaelis constant for NADP and glucose-6-phosphate ( $\mathrm{G} 6 \mathrm{P}$ ) was lower than the control. Conversely, the utilization of the analogous 2-deoxyglucose-6-phosphate (2dG6P) and galactose-6-phosphate (Ga16P) was higher. The thermostability of the enzyme in the deficient subjects was lower and the $\mathrm{pH}$ optima ( 8 and 9.5 ) were different from the controls. An identical electrophoretic pattern was found in both normal and deficient subjects. The bactericidal activity in the deficient subjects was normal. There was no difference in the results of nitroblue tetrazolium (NBT) tests in either group.

\section{Speculation}

Although leukocyte G6PD was only one-quarter of the normal level, the phagocytic activity and the NBT test were normal in all subjects studied. It is not clear how such low levels of enzyme allow normal function. Perhaps further investigation under simulated intracellular conditions could give more reliable information about the enzyme activity.

During bactericidal activity phagocytes of peripheral blood utilize aerobic glycolysis with activation of hexosomonophosphate shunt (HMPS). The first step of HMPS is the breakdown of glucose-6-phosphate by G6PD which causes the reduction of NADP to NADPH. In the absence of G6PD the shunt is not activated and the bactericidal activity of phagocytes is blocked. In fact, Caucasians have been reported with absence of leukocyte G6PD associated with recurrent bacterial and fungal infections with a clinical picture similar to that of chronic granulomatous disease (CGD) $(1,5,7)$. Normal bactericidal activity has been found in Caucasians with leukocyte G6PD rate ranging from $20 \%$ to $50 \%$ of normal value $(2,5)$. In all of these cases, G6PD has not been characterized.

We examined Sicilian boys with erythrocyte G6PD deficiency to see if there were anomalies of bactericidal activity in peripheral blood phagocytes. The type of deficiency was established by studying some kinetic and biophysical characteristics of their leukocytic G6PD. 


\section{MATERIALS AND METHODS}

We examined nine Sicilian male children varying in age from 3-8 years, all of whom in the past had experienced hemolytic crises of favism. Nine normal children served as control subjects.

The leukocytes were isolated from $30 \mathrm{ml}$ blood by the method reported by Schilirò et al. (19). Some of the leukocytes were used for bactericidal activity test and for the NBT test; the remainder were lysed and served for G6PD characterization.

The bactericidal activity for Staphylococcus aureus (A.T.C.C. 6538) was tested by the method of Quie et al. (11).

The NBT test was carried out by the method of Baehner and Nathan (2). The centrifugations were performed with a Beckman Spinco L2 centrifuge. A Beckman DU spectrophotometer was used. Substrates and NBT were from Sigma Chemical Co., St. Louis, Mo. The other chemical products were from E. Merck A.G., Darmstadt, Germany.

For electrophoresis of G6PD we followed the technique reported by Rattazzi et al. (14). We determined the optimum $\mathrm{pH}$ using a buffer of Tris-phosphate and glycine in a final concentration of $0.05 \mathrm{M}$, adjusted to the desired $\mathrm{pH}$ with $\mathrm{NaOH}$ or $\mathrm{NaCl}$.

The values are expressed as the percentage of the value obtained at $\mathrm{pH}$ 7.5. The Michaelis constant $\left(\mathrm{K}_{\mathrm{m}}\right)$ for G6PD was studied with five different concentrations of substrate with molarity varying from $2 \mathrm{mM}$ to $0.025 \mathrm{mM}$; for NADP we used five concentrations of substrate varying from $1 \mathrm{mM}$ to $0.025 \mathrm{mM}$.

For the study of the utilization of 2-deoxy-6-phosphate and Gal6P the molarity of the substrates was $0.02 \mathrm{mM}$. The rate of utilization was expressed as a percentage of the value obtained with G6P.

For the study of thermolability, leukocyte lysate was put in a thermostated bath at $41^{\circ}$. Every $20 \mathrm{~min}$ aliquots of $0.10 \mathrm{ml}$ were immediately put in a thermostated bath at $2^{\circ}$; then the G6PD activity at $25^{\circ}$ was determined. G6PD activity was measured according to the method of Zinkham et al. (24), and expressed as $\mathrm{mM}$ NADP reduced to NADPH in $1 \mathrm{~min}$ at $25^{\circ}$.

Erythrocyte activity was referred to $100 \mathrm{ml}$ erythrocytes and leukocyte G6PD activity was expressed in milligrams of protein.

The proteins were measured according to the method of Lowry et al. (9).

\section{RESULTS}

In all of the deficient subjects, the average erythrocyte G6PD activity was $1.6 \pm 1.35$. The G6PD levels in the leukocytes were found to be reduced with an average of $0.094 \pm 0.03$ corresponding to $26 \%$ of the controls. The difference is statistically significant $(P$ $<0.01$ ) (Table 1).

The biochemical and biophysical characteristics of the G6PDdeficient subjects were quite different from normal findings. Figure 1 shows the average rates of heat inactivation in the deficient and normal subjects. The enzyme activity of normal subjects shows a gradual and uniform decrease to $50 \%$ in $\mathrm{l} \mathrm{hr}$, whereas the enzyme activity in deficient subjects drops to $12 \%$ in only 20 min and falls to $5 \%$ in $1 \mathrm{hr}$.

Figure 2 shows the enzyme activity in relation to $\mathrm{pH}$ increasing steadily up to $\mathrm{pH} 8.5$ and then gradually decreasing. In all deficient subjects the $\mathrm{pH}$ was bimodal with $\mathrm{pH}$ optimum at 8 and 9.5. The $\mathrm{K}_{\mathrm{m}}$ for G6PD and NADP was found to be lower in the deficient subjects than in normal subjects (Table 2).

Table 1. Glucose-6-phosphate dehydrogenase (G6PD) activity of erythrocytes and leukocytes in normal and mutant subjects

\begin{tabular}{cccc}
\hline Subjects & Number & $\begin{array}{c}\text { Erythrocyte } \\
\text { G6PD, } \\
\text { U/100 ml }\end{array}$ & $\begin{array}{c}\text { Leukocyte } \\
\text { G6PD, U/mg } \\
\text { protein }\end{array}$ \\
\hline Normal & 9 & $133 \pm 18$ & $0.360 \pm 0.12$ \\
Mutant & 9 & $1.6 \pm 1.35$ & $0.094 \pm 0.03$ \\
\hline
\end{tabular}

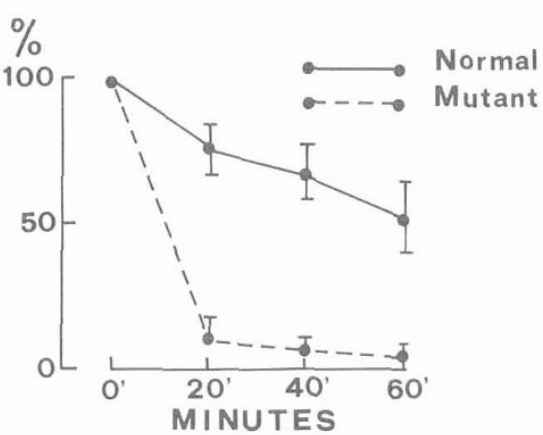

Fig. 1. Heat stability of leukocyte glucose-6-phosphate dehydrogenase at $41^{\circ}$ (mean values from nine normal and nine mutant subjects).

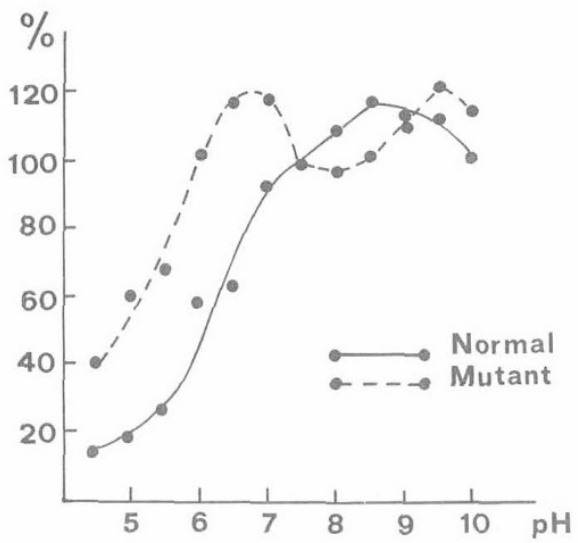

Fig. 2. Optimal pH curves of leukocyte glucose-6-phosphate dehydrogenase (mean values from nine normal and nine mutant subjects).

Table 2. Biochemical characteristics of glucose-6-phosphate dehydrogenase (G6PD) in normal and mutant subjects ${ }^{1}$

\begin{tabular}{|c|c|c|c|c|}
\hline \multirow[b]{2}{*}{ Subjects } & \multirow{2}{*}{$\begin{array}{c}\mathrm{K}_{\mathrm{m}} \text { for } \\
\mathrm{NADP}, \\
\mu \mathrm{M}\end{array}$} & \multirow{2}{*}{$\begin{array}{c}\mathrm{K}_{\mathrm{m}} \text { for } \\
\mathrm{G} 6 \mathrm{P}, \\
\mu \mathrm{M}\end{array}$} & \multicolumn{2}{|c|}{$\begin{array}{c}\text { Substrate analog } \\
\text { utilization }^{2}\end{array}$} \\
\hline & & & Gal6P & 2dG6P \\
\hline \multicolumn{5}{|l|}{ Mutant subject } \\
\hline 1 & 1.8 & 10 & 30 & 89 \\
\hline 2 & 2 & 18 & 85 & 85 \\
\hline 3 & 2.4 & 14 & 85 & 80 \\
\hline 4 & 1.6 & 10 & 72 & 65 \\
\hline 5 & 1.8 & 20 & 20 & 45 \\
\hline 6 & 1.4 & 22 & 10 & 22 \\
\hline 7 & 2 & 12 & 70 & 28 \\
\hline 8 & 2.2 & 18 & 60 & 20 \\
\hline 9 & 1.6 & 22 & 50 & 22 \\
\hline \multicolumn{5}{|l|}{ Normal subject } \\
\hline 1 & 6 & 60 & 28 & 5 \\
\hline 2 & 7.5 & 68.8 & 26 & 8 \\
\hline 3 & 4.4 & 74 & 22 & 8 \\
\hline 4 & 3.8 & 40.5 & 20 & 12 \\
\hline 5 & 5 & 38.6 & 18 & 12 \\
\hline 6 & 5.2 & 68.2 & 10 & 5 \\
\hline 7 & 4.3 & 70 & 8 & 6 \\
\hline 8 & 3.2 & 40 & 20 & 8 \\
\hline 9 & 2.9 & 48.8 & & 6 \\
\hline
\end{tabular}

G6P: glucose-6-phosphate; Gal6P: galactose-6-phosphate; 2dG6P: 2-deoxyglucose-6-phosphate.

${ }^{2}$ Activity expressed as percentage of the activity of G6P. 
The enzyme of deficient subjects showed a greater affinity for the homologous 2dG6P and Gal6P than that of the normal subjects (Table 2).

An identical electrophoretic pattern was found both in normal and deficient subjects (Fig. 3).

The bactericidal activity in the deficient subjects was normal, There was no difference in the results of the NBT test between the two groups (Table 3 ).

\section{DISCUSSION}

The results confirm that in G6PD-deficient Sicilian boys enzyme leukocyte activity, although low, is present, as has always been the case in the Mediterranean variant $(4,8,10,13,17)$.

The enzyme of our deficient subjects also shows a greater affinity for the substrates G6P and NADP, for the homologous 2dG6P and Gal6P; the curve of $\mathrm{pH}$ activity shows two peaks at $\mathrm{pH}$ 7 and 9.5. These characteristics are typical of the Mediteranean variant $(4,8,12,17)$.

In all subjects examined the phagocytic and bactericidal activity was found to be normal; the results of NBT tests were also normal. These findings show that even one-quarter of enzyme activity allows normal phagocytic activity in the Mediterranean variant. Spire et al. (21) found normal NBT tests in 42 subjects previously affected by favism. In these cases leukocyte G6PD levels have not been measured. Rodey et al. (15) found normal leukocyte function in two Caucasian patients in whom enzyme leukocyte activity was $25 \%$ of the normal. Baehner et al. (1) found normal leukocytic

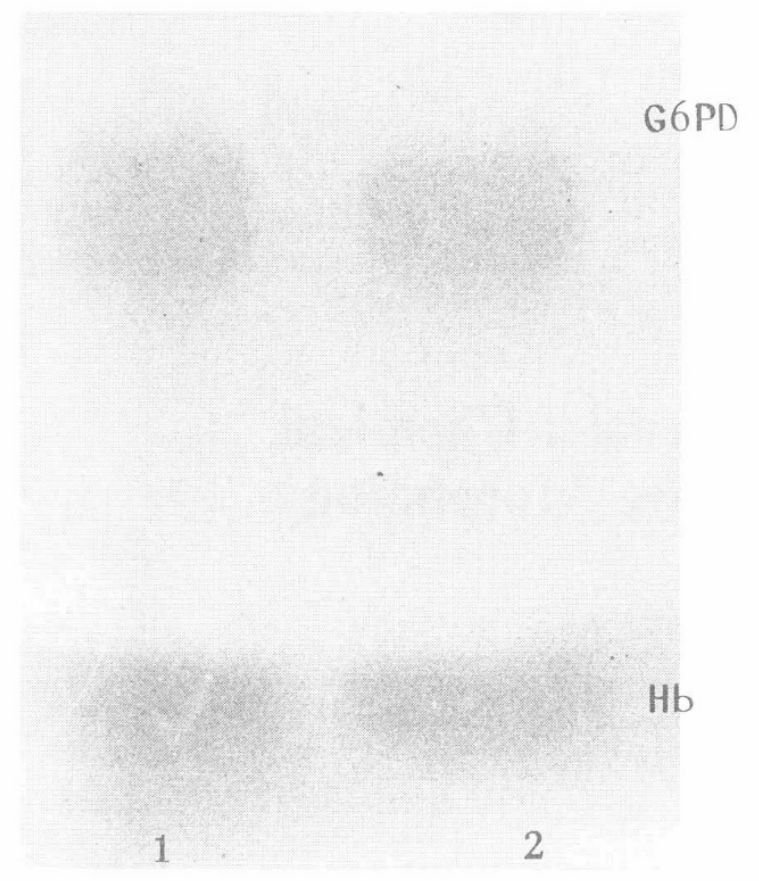

Fig. 3. Cellogel electrophoresis of glucose-6-phosphate dehydrogenase (G6PD). 1: G6PD normal leukocyte; 2: G6PD mutant leukocyte.

Table 3. Results of polymorphonuclear $(P M N)$ bactericidal activity and nitroblue tetrazolium (NBT) test reduction in normal and mutant subjects

\begin{tabular}{cccc}
\hline Subjects & Number & $\begin{array}{c}\text { Bactericidal } \\
\text { activity }\end{array}$ & $\begin{array}{c}\text { Quantitative } \\
\text { NBT test }^{2}\end{array}$ \\
\hline Normal subject & 9 & $90-95$ & $0.210 \pm 0.18$ \\
Mutant subject & 9 & $90-95$ & $0.231 \pm 0.20$ \\
\hline
\end{tabular}

${ }^{1}$ Percentage of staphylococci killed at $60 \mathrm{~min}$.

${ }^{2} \Delta \mathrm{OD}$ per $15 \mathrm{~min}$ per $2.5 \times 10^{6} \mathrm{PMN}$. function in eight Caucasian patients with leukocyte G6PD activity ranging from $20 \%$ to $50 \%$ of the normal. Only the absence of G6PD produces decreased leukocyte bactericidal and metabolic activity with a clinical picture of CGD.

Cooper et al. (5) described a 52-year-old Caucasian female patient with chronic hemolytic anemia, leukemoid reaction, and fatal sepsis. Her leukocytes had complete G6PD deficiency and inadequate bactericidal activity. Three Caucasian patients of pediatric age with similar clinical picture and metabolic anomalies have been described by Gray et al. (7). Baehner et al. (1) reported a Caucasian boy with 1 G6PD at $1 \%$ of normal levels and related metabolic anomalies without an increased incidence of infections.

Bellanti et al. (3) found an accelerated decay of G6PD activity in children with chronic granulomatous disease. A similar decrease of enzyme activity was present in all our G6PD-deficient subjects after $20 \mathrm{~min}$ of incubation at $41^{\circ}$. However, unlike the patients of Bellanti et al. (3), the decrease was not associated with decreased bactericidal activity. We think, therefore, that the involvement of bactericidal activity in CGD is independent of G6PD lability. In fact, Erickson et al. (6) demonstrated that G6PD lability in CGD is due to a lack of stabilizing factors. Sococcia et al. (20) showed that G6PD in intact leukocytes of the CGD is functionally normal.

We think that the biochemical and biophysical characteristics of leukocyte G6PD in our subjects do not depend on the lack of stabilizing factors. In fact, we characterized the partially purified erythrocyte G6PD in five of these cases (mutant subjects $1-5$, Table 2) (19). The purification and characterization were carried out according to the method suggested by the experts from WHO (22), which includes the dialysis and the addition of NADP and $\beta$-mercaptoethanol to the hemolysate. Their $\mathrm{pH}$ activity curve, their affinity for the substrates G6P, NADP, and for the homologous 2dG6P and Gal6P, as well as their heat lability were identical in leukocyte and purified erythrocyte G6PD.

It is not clear how low levels of enzymatic activity (about 20\%) can allow normal bactericidal activity. According to the data of Rodey et al. (15), in the leukocytes normal levels of G6PD are more than sufficient, because even if there is a marked decrease normal leukocyte function continues. However, another explanation may be that of Yoshida (23), who showed that the findings in vitro do not reflect the kinetic behavior and enzyme activity in vivo. Only a study "under simulated intracellular conditions" gives an accurate picture of enzyme activity. Indeed, enzyme activity of the erythrocyte in the Mediterranean variant, studied under conditions which resemble the intracellular environment, reaches $30 \%$ and is sufficient to protect the red cell.

The low levels of leukocyte enzymatic activity found in vitro do not correspond with the higher levels found in intracellular environment. This fact could explain the normal leukocyte function in mutant subjects.

Our studies confirm that in the Mediterranean variant the leukocytic function is not impaired.

In fact, in Sicily, where G6PD deficiency has a frequency of $1.7 \%$ (16), we have not observed any G6PD-deficient subject with particular susceptibility to infections.

The absence of leukocyte G6PD, nonspherocytic hemolytic anemia, and CGD in the four patients reported by Cooper et al. (5) and by Gray et al. (7) could be due to another severe enzymatic variant, possible deletion, or a defect in transcription.

\section{SUMMARY}

Bactericidal activity and quantitative nitroblue tetrazolium test of leukocytes of nine G6PD-deficient Sicilian children and of nine normal control subjects have been studied. Leukoycte G6PD was only one-quarter normal level. The biochemical and biophysical characteristics of leukocyte G6PD in our deficient subjects were those of the Mediterranean variant. Leukocyte function tests were normal in both series of subjects. These results suggest that neither the low levels of this enzyme nor its heat lability impairs leukocyte function. In fact, the susceptibility to infections of G6PD-deficient subjects is not increased. 


\section{REFERENCES AND NOTES}

1. Baehner, L. R., Johnston, R. B., and Nathan, D. G.: Comparative study of the metabolic and bactericidal characteristics of severely glucose-6-phosphate dehydrogenase deficient polymorphonuclear leukocytes and leukocytes from children with chronic granulomatous disease. J. Reticuloendothel. Soc., 12: 150 (1972).

2. Baehner, L. R., and Nathan, D. G.: Quantitative nitroblue tetrazolium test in chronic granulomatous disease. New Engl. J. Med., 278: 971 (1968)

3. Bellanti, J. A., Cantz, B. E., and Schlegel, R. J.: Accelerated decay of glucose-6-phosphate dehydrogenase activity in chronic granulomatous disease. Pediat. Res., 4: 405 (1970).

4. Bonsignore, A., Fornaini, G., Leoncini, G., Fantoni, A., and Segni, P.: Characterization of leukocyte glucose-6-phosphate dehydrogenase in Sardinian mutants. J. Clin. Invest., 45: 1865 (1966).

5. Cooper, M. R., DeChatelet, L. R., McCall, C. E., LaVia, M. F., Spurr, C. L. and Baehner, L. R.: Complete deficiency of leukocyte glucose-6-phosphate dehydrogenase with defective bactericidal activity. J. Clin. Invest., 51: 769 (1972).

6. Erickson, R. P., Stites, D. P., Fudenberg, H. H., and Epstein, C. J.: Altered levels of glucose-6-phosphate dehydrogenase stabilizing factors in X-linked chronic granulomatous disease. J. Lab. Clin. Med., 80: 645 (1972).

7. Gray, G, R, Klebanoff, S, J., Stamatoyannopoulos, G., Austin, T., Naiman, S. C., Yoshida, A., Kliman, M. R., and Robinson, G. C. F.: Neutrophil dysfunction, chronic granulomatous disease and nonspherocytic haemolytic anaemia caused by complete deficiency of glucose-6-phosphate dehydrogenase. Lancet, ii: 530 (1973).

8. Justice, P., Shih, L., Gordon, J., Grossman, A., and Hsia, D. Y.: Characterization of leukocyte glucose-6-phosphate dehydrogenase in normal and mutant human subject. J. Lab. Clin. Med., 68: 552 (1966).

9. Lowry, O. H., Rosebrough, N. J., Farr, A. L., and Randall, R. J.: Protein measurement with the Folin phenol reagent. J. Biol. Chem., 193: 265 (1951).

10. Marks, P. A., and Gross, R. T.: Erythrocyte glucose-6-phosphate dehydrogenase deficiency: Evidence of difference between Negroes and Caucasians with respect to this genetically determined trait. J. Clin. Invest., 38: 2253 (1959).

11. Quie, P. G., White, J. G., Holmes, B., and Good, R. A.: In vitro bactericidal capacity of human polymorphonuclear leukocytes: Diminished activity in chronic granulomatous disease of childhood. J. Clin Invest., 46: 668 (1967).

12. Ramot, B., Bauminger, S., Brok, D., Gafni, D., and Scwartz, S.: Characterization of glucose-6-phosphate dehydrogenase in Jewish mutants. J. Lab. Clin. Med., 64: 895 (1964).

13. Ramot, B., Fisher, S., Szeinberg, A., Adams, A., Sheba, C., and Gafni, D.: A study of subjects with erythrocyte glucose-6-dehydrogenase deficiency. II. Investigation of leukocyte enzyme. J. Clin. Invest., 38: 2234 (1959).

14. Rattazzi, M. C., Bernini, L. F. Fiorelli, G., and Mannucci, P. M., Electrophoresis of glucose-6-phosphate dehydrogenase: A new technique. Nature, 213: 79 (1967)

15. Rodey, G. E., Jacob H. S., Holmes, B., McArthur, J. R., and Good, R. A.: leukocyte G6PD levels and bactericidal activity, Lancet, $i \cdot 335$ (1970).

16. Russo, G.: Il favismo in Sicilia. Riv. Pediat. Sic., 22: 296 (1967)

17. Russo, G., Schilirò, G., and Gallone, G.: Caratterizzazione della carenza di G6FD in soggetti Siciliani. Riv. Pediat., 29: 296 (1969).

18. Schilirò, The G6PD deficiency in Sicili. (In press.)

19. Schilirò, G., Gallone, G., and Distefano, G.: Caratterizzazione del difetto di G6FD nella popolazione siciliana. Nota 1: Livelli di attività enzimatica leucocitaria. Riv. Pediat. Sic., 23: 533 (1968).

20. Sococcia, P., Holmes, B., and Good, R. A.: Unpublished observations cited by B. Holmes. In: R. C. Williams and H. H. Fudenberg: Phagocytic Mechanisms in Health and Disease, p. 57 (Georg Thieme, Stuttgart, 1972).

21. Spire, Z., Binor, Z., and Bogair, N.: G6PD and childhood infection. Lancet, ii. 661 (1971).

22. World Health Organization: Series de rapport techniques 1967 no. 366.

23. Yoshida, A.: Hemolytic anemia and G6PD deficiency. Science, 179: 532 (1973).

24. Zinkham, W. H. Lenhard, R. E., Jr., and Childs, B. A.: A deficiency of glucose-6-phosphate dehydrogenase activity in erythrocytes from patients with favism. Bull. Johns Hopkins Hosp., 102: 169 (1958).

25. Requests for reprints should be addressed to: G. Schilirò, M.D., Department of Pediatrics, V. le A. Doria, 95100 Catania (Italy).

26. Accepted for publication March 3, 1976
Acini

calcium

cystic fibrosis lobular ducts pancreas morphology islets

\title{
The Pancreas in Cystic Fibrosis: Chemical Composition and Comparative Morphology
}

\author{
L. E. KOPITO AND H. SHWACHMAN ${ }^{123}$ \\ Department of Clinical Nutrition, The Ina Sue Perlmutter Cystic Fibrosis Center, The Children's Hospital \\ Medical Center, and the Department of Pediatrics, Harvard Medical School, \\ Boston, Massachusetts, USA \\ G. F. VAWTER AND J. EDLOW \\ Department of Pathology, The Children's Hospital Medical Center and Harvard Medical School, \\ Boston, Massachusetts, USA
}

Extract

Sections of pancreas from 16 individuals who died with cystic fibrosis (CF) were classified by morphometric criteria into four categories in increasing order of pancreatic involvement. The concentration of acini, islets, main ducts, lobular ducts, connective tissue, and fat was compared with control levels. The results show that in the least involved pancreases, from neonates who died under 5 months of age, acini were reduced to $33 \%$ of control levels and the following were increased: islets, to $410 \%$; lobular ducts, to $250 \%$; and main ducts, to $1700 \%$ of controls.

With increasing severity of the pancreatic disease the acini were further reduced to $5 \%$ and lobular ducts to $37 \%$ of control levels, respectively. Main ducts increased by 19 -fold, and fatty infiltration accounted for more than $25 \%$ of the fresh weight of the pancreas in 9 of the 16 specimens.

Comparative biochemical studies of 35 fibrocystic pancreases were quantitatively related to the severity of the pancreatic involvement as follows. Water and volatile matter, normally accounting for $80_{ \pm} \%$ of the weight of the fresh pancreas, was reduced to less than $30 \%$ in the most affected organs. The concentration of zinc diminished from near normal mean levels of $193 \mu \mathrm{g}$ $\mathrm{Zn} / \mathrm{g}$ dry pancreas to $10 \%$ of this amount in the severely involved pancreas. 